\title{
Drones, Afghanistan, and beyond: Towards analysis and assessment in context
}

\author{
James Michael Page* (D) and John Williams \\ School of Government and International Affairs, Durham University, Durham, United Kingdom \\ *Corresponding author. Email: james.page@durham.ac.uk
}

(Received 11 August 2020; revised 26 July 2021; accepted 9 August 2021; first published online 1 October 2021)

\begin{abstract}
Afghanistan is one of the most drone-affected states, however, very few scholarly studies of drone use there exist. This article uses original fieldwork data in a strategically important area of Afghanistan, eastern Nangarhar province, to analyse drone effects in context. It raises important concerns about the ability of the US to attain stated counterterrorism and counterinsurgency goals. Our results show contextualised analysis of drone use necessitates appropriate enquiry into policy, doctrine, and local circumstances. It also reveals serious incoherence, inaccurate assumptions, and insufficient appreciation of local circumstances and dynamics not only in US policy and doctrine, but also numerous scholarly studies of drone use effectiveness. This has far-reaching policy, operational, and research implications, including regarding local communities' governance, relations, and resilience to insurgent and terrorist encroachment. Therefore, we contribute to debates about how to analyse and assess drone use and its effects, why drone analysis needs to change, and what more effective forms of research and analysis can reveal.
\end{abstract}

Keywords: Drones; Afghanistan; Policy and Strategy; Terrorism and Insurgency; Counterterrorism and Counterinsurgency

\section{Introduction}

Very few scholarly studies into drone use focus specifically on Afghanistan. ' $[\mathrm{I}]$ nternational forces [in Afghanistan] have shown a marked reluctance to discuss the use of drones', ${ }^{2}$ and after 2003, media reporting shifted to Pakistan and Iraq, ${ }^{3}$ resulting in an 'informational black hole' about drone use in Afghanistan. ${ }^{4}$ Afghanistan's significance is considerable as contemporary US drone strike operations first occurred there in $2001{ }^{5}$, and drones' roles and activities in counterinsurgency and counterterrorism campaigns in Afghanistan have shaped those in Iraq, Yemen, Pakistan, Syria, Libya, Somalia, and further afield. We argue analysing and assessing drone use in Afghanistan - our focus - or elsewhere is best done in appropriate context, including inter alia: policy goals; targeted 'enemies'; and, local political, cultural, and social conditions.

${ }^{1}$ Larry Lewis and Sarah Holewinski, 'Changing of the guard: Civilian protection for an evolving military', PRISM, 4:2 (2013), pp. 57, 60; Larry Lewis, 'Drone Strikes: Civilian Casualty Considerations (Unclassified Executive Summary)', Center for Naval Analyses (18 June 2013).

${ }^{2}$ Alice K. Ross, Jack Serle, and Tom Wills, 'Tracking Drone Strikes in Afghanistan: A Scoping Study', The Bureau of Investigative Journalism (July 2014), p. 5.

${ }^{3}$ Christopher Drew, 'Drones are playing a growing role in Afghanistan', New York Times (19 February 2010).

${ }^{4}$ Ann Rogers and John Hill, Unmanned: Drone Warfare and Global Security (London, UK: Pluto Press), p. 95.

${ }^{5}$ The first US drone strike occurred in Afghanistan on 7 October 2001, Chris Woods, Sudden Justice: America's Secret Drone Wars (London, UK: Hurst, 2015), pp. 23-7, 38-9. Regarding drone emergence and Afghanistan's significance, see pp. 4, 21-7, 40-5, 144-51, 243-51.

(C) The Author(s), 2021. Published by Cambridge University Press on behalf of the British International Studies Association. This is an Open Access article, distributed under the terms of the Creative Commons Attribution-NonCommercial-ShareAlike licence (https://creativecommons. org/licenses/by-nc-sa/4.0/), which permits non-commercial re-use, distribution, and reproduction in any medium, provided the same Creative Commons licence is included and the original work is properly cited. The written permission of Cambridge University Press must be obtained for commercial re-use. 
Fieldwork conducted in locations in eastern Nangarhar province, a strategically important area of Afghanistan, provides rich and informative accounts of drone use. Analysing these in context reveals details of its effects on local and other populations. This raises important concerns about the ability of the US to attain stated counterinsurgency and counterterrorism goals, and substantially adds to existing drone use study findings and debates. Our results show that contextualised analysis of drone use necessitates enquiry into local circumstances, issues of policy, and doctrine. In the Afghanistan case, US policy, doctrine, and consequent operations involve not only serious incoherence, but also inaccurate assumptions about context, and insufficient appreciation of local circumstances and dynamics. This has far-reaching ramifications, for example, drone use in the fieldwork period was found to have seriously undermined governance institutions in the fieldwork locations, and beyond. These have a key historical and contemporary role in regulating communities in these locations (and others), their relations with the national authorities, and resistance to those encroaching or threatening them, such as terrorists and insurgents. Therefore, in this study we contribute to debates about how to analyse and assess drone use and its effects, demonstrating the usefulness of contextual approaches including methods drawn from anthropology, and we also contribute to findings and debates about drone use effects and their implications. Similar studies elsewhere in Afghanistan, and other locations subject to drone use, have much to offer. However, we indicate why drone analysis needs to change, and what more effective forms of research and analysis can reveal.

The article proceeds as follows. Section 1 argues existing studies overlook important contextual factors resulting in effectiveness claims that are too narrowly drawn and misleading assessments. Prominent quantitative studies conflate important categories, make inapt assumptions about comparability across locations, and lack perspective on key concepts. Effective criticisms exist of more qualitative studies looking at local populations' drone experiences, but these are not inherent to qualitative studies. ${ }^{6}$ Furthermore, we show incoherence in counterterrorism and counterinsurgency doctrine, particularly envisaged policy goals and underpinning conceptualisations.

Section 2 describes our fieldwork methodology and its context. Michael J. Boyle's 'potentially offsetting effects' are developed as an appropriate framework for contextually analysing drone use. As we show, although this required amendment for specific context, Boyle's categories of 'popular backlash', 'counter-mobilisation of enemy networks', 'legitimacy gap', and 'leverage' enable appropriately contextualised analysis. ${ }^{7}$ This framework could be used in different contexts, including outside Afghanistan, if tailored with appropriate care.

Section 3 explores fieldwork results showing how these populations experience and understand drones and their uses through, firstly, quotidian cultural, social and economic practices; and, secondly, local (in)security, and their perception of the role of different actors. Results show a consistent and specific pattern of drone-impacted governance eroding the population's deep-rooted resistance to terrorist/insurgent activities, militating against achieving counterterrorism and counterinsurgency goals in these locations and elsewhere.

Our study addresses important research gaps in analysing and assessing drone effectiveness by taking into account wider effects and implications of drone use including in the under-researched case of Afghanistan. It does so by carefully considering policy goals, concurrent counterterrorism and counterinsurgency, and appropriate context, including cultural and societal factors. It does not seek to definitively determine whether drone use is effective or not, given, as we show, the importance of context and circumstance in reaching such judgements.

\footnotetext{
${ }^{6} \mathrm{~A}$ key target for such critique is James Cavallaro et al., Living Under Drones: Death, Injury and Trauma to Civilians from US Drone Practices in Pakistan (New York, NY: International Human Rights and Conflict Resolution Clinic, Stanford Law School); New York University School of Law, Global Justice Clinic (2012). See Aqil Shah, 'Do U.S. drone strikes cause blowback? Evidence from Pakistan and beyond', International Security, 42:4 (2018), p. 52; C. Christine Fair, 'Ethical and methodological issues in assessing drones' civilian impacts in Pakistan', Washington Post (6 October 2014).

${ }^{7}$ Michael J. Boyle, 'Do counterterrorism and counterinsurgency go together?', International Affairs, 86:2 (2010), pp. 333-53.
} 


\section{Drones and context}

\subsection{Academic analysis}

Drone use in counterterrorism and/or counterinsurgency has become closely associated with targeted killing and/or leadership decapitation, ${ }^{8}$ against terrorist and/or insurgent groups. Numerous empirical studies analyse and assess effectiveness, including some qualitative case-based studies across a range of contexts. ${ }^{9}$ There is not a consensus about the effectiveness of targeted killing/decapitation or the use of drones. Stephen R. David's and Daniel Byman's qualitative studies focus on the Israel-Palestine context, finding targeted killing/decapitation can be effective in conjunction with other measures. ${ }^{10}$ Among such studies, only Alex S. Wilner focuses on Afghanistan, ${ }^{11}$ however, only one of his four cases of targeted killing may have involved a drone (Mullah Mahmud Baluch). His results showed short-term changes to Taliban effectiveness, professionalism and motivation.

Other studies use aggregated statistical data across a range of contexts, for example Aaron Mannes, Jenna Jordan, Bryan C. Price, Abrahms and Potter (in counterterrorism), Thomas H. Johnston (in counterinsurgency), Max Abrahms and Jochen Mierau (against militants). ${ }^{12}$ None focus specifically on drones. Other studies focus on more particular contexts and on drones, such as David A. Jaeger and Zahra Siddique, and Abrahms and Mierau on Pakistan and Afghanistan, and Patrick B. Johnston and Anook K. Sarbahi, Asfandyar Mir and Dylan Moore, and Anouk S. Rigterink on Pakistan. ${ }^{13}$ Despite sharing quantitative approaches, these studies of targeted killing/decapitation employ different definitions, data, methodologies, and measures of effectiveness, from the rate of terrorist or insurgent attacks to groups' lifespans and even propaganda output, ${ }^{14}$ making comparisons between them difficult. Aggregate studies (from different contexts) suggest or claim targeted killing/decapitation speeds up the decline

\footnotetext{
${ }^{8}$ Targeted killing can refer to any individual, unless qualified. Reference to decapitation in such studies is usually to the (targeted) killing of leadership figures and/or their arrest/capture, for example, Aaron Mannes, 'Testing the snake head strategy: Does killing or capturing its leaders reduce a terrorist group's activity?', Journal of International Policy Solutions, 9 (2008), pp. 40-9; Jenna Jordan, 'When heads roll: Assessing the effectiveness of leadership decapitation', Security Studies, 18:4 (2009), pp. 719-55; Patrick B. Johnston, 'Does decapitation work? Assessing the effectiveness of leadership targeting in counterinsurgency campaigns', International Security, 36:4 (2012), pp. 47-79; Bryan C. Price, 'Targeting top terrorists: How leadership decapitation contributes to counterterrorism', International Security, 36:4 (2012), pp. 9-46. Exceptions, referring to decapitation as only killing, include: Max Abrahms and Philip Potter, 'Explaining terrorism: Leadership deficits and militant group tactics', International Organization, 69:2 (2015), pp. 311-42; Max Abrahms and Jochen Mierau, 'Leadership matters: The effects of targeted killings on militant group tactics', Terrorism and Political Violence, 29:5 (2017), pp. 830-51.

${ }^{9}$ Matt Frankel, 'The ABCs of HVT: Key lessons from high value targeting campaigns against insurgents and terrorists', Studies in Conflict \& Terrorism, 34:1 (2010), pp. 17-30; Keith Patrick Dear, 'Beheading the hydra? Does killing terrorist or insurgent leaders work?', Defence Studies, 13:3 (2013), pp. 293-337; Daniel Byman, 'Why drones work: The case for Washington's weapon of choice', Foreign Affairs, 92:4 (2013), pp. 32-43; Audrey Kurth Cronin, 'Why drones fail: When tactics drive strategy', Foreign Affairs, 92:4 (2013), pp. 44-54.

${ }^{10}$ Steven R. David, 'Israel's policy of targeted killing', Ethics and International Affairs, 17:1 (2003), pp. 111-26; Daniel Byman, 'Do targeted killings work?', Foreign Affairs, 85:2 (2006), pp. 95-111.

${ }^{11}$ Alex S. Wilner, 'Targeted killings in Afghanistan: Measuring coercion and deterrence in counterterrorism and counterinsurgency', Studies in Conflict \& Terrorism, 33:4 (2010), pp. 307-29.

${ }^{12}$ Mannes, 'Testing the snake head strategy'; Jordan, 'When heads roll'; Jordan Jenna, 'Attacking the leader missing the mark: Why terrorist groups survive decapitation strikes', International Security, 38:4 (2014), pp. 7-38; Price, 'Targeting top terrorists'; Johnston, 'Does decapitation work?'; Abrahms and Potter, 'Explaining terrorism'; Abrahms and Mierau, 'Leadership matters'.

${ }^{13}$ Patrick B. Johnston and Anook K. Sarbahi, 'The impact of US drone strikes on terrorism in Pakistan', International Studies Quarterly, 60:2 (2016), pp. 203-19; David A. Jaeger and Zahra Siddique, 'Are Drone Strikes Effective in Afghanistan and Pakistan? On the Dynamics of Violence between the United States and the Taliban' (Bonn, Germany: Forschungsinstitut zur Zukunft der Arbeit [IZA Institute of Labor Economics], December 2011); Asfandyar Mir and Dylan Moore, 'Drones, surveillance, and violence: Theory and evidence from a US drone program', International Studies Quarterly, 63:4 (2019), pp. 846-62; Anouk S. Rigterink, 'The wane of command: Evidence on drone strikes and control within terrorist organizations', American Political Science Review, 115:1 (2020), pp. 31-50.

${ }^{14}$ Megan Smith and James Igoe Walsh, 'Do drone strikes degrade Al Qaeda? Evidence from propaganda output', Terrorism and Political Violence, 25:2 (2013), pp. 311-27.
} 
of insurgent or terrorist organisations or diminishes the number or intensity of their attacks, ${ }^{15}$ while others suggest it makes little, if any, difference or may be counterproductive. ${ }^{16}$ As with aggregate quantitative studies of the effectiveness of targeted killings across numerous contexts those focused on Pakistan and Afghanistan, ${ }^{17}$ and on Pakistan, also see no consensus. ${ }^{18}$

A recurrent difficulty is studies of targeted killing/decapitation addressing Afghanistan and Pakistan, including specifically through drone strikes, rarely differentiate between them. Jaeger and Siddique, for example, considered drone strikes mainly in Pakistan, but assess their effect on violence in Afghanistan (but not drone strikes in Afghanistan). Similarly, Johnston and Sarbahi analysed drone strikes in the FATA (Federally Administrated Tribal Areas) region of Pakistan (merged with Khyber Pakhtunkhwa province in 2018), not Afghanistan, but analysed the effect of these strikes on militant violence in FATA, in other parts of Pakistan, and neighbouring areas of Afghanistan. Abrahms and Potter also considered targeted killing of militant groups' leadership in 'Afghanistan-Pakistan tribal regions', but do not distinguish between them. More seriously, Abrahms and Mierau treat 'Taliban' as a single organisation (which they are not), thereby conflating Afghan and Pakistan Taliban, and also aggregate strikes in Afghanistan and Pakistan. Although similar rather narrowly construed accounts of 'effectiveness' are employed in these studies, such as levels of violence, there are important variations in data sources, treatment, and analysis using a variety of statistical techniques. However, important differences between terrorist and insurgent groups involved are neglected, such as contextualising their different forms, modes of action, and goals. Nor are differences between counterterrorism and counterinsurgency considered. Rigterink, in her study of drone strikes in Pakistan and some in Afghanistan, differentiates between different groupings using 'Taliban' in their titles, but treats them all as 'terrorist' groups, ignoring their role in insurgencies. Considerable analytical cost arises, as important differences between groups, their political agendas, activities, and interactions are set aside. Furthermore, none of these studies show interest in effects of targeted killing on local populations much beyond the extent to which they may be victims of increased terrorist violence.

Aqil Shah's evaluation of a 'drone blowback thesis' is an exception to such narrow focus on effects of targeted killing/decapitation, including by drones in Pakistan. This thesis postulates drone use effects, 'such as civilian casualties, military operations, mental distress, [and] displacement', lead to increased 'militant recruitment, and militancy'. ${ }^{19}$ Shah's qualitative, primarily interview-based, study refutes the thesis. However, broader enquiry into effects of drone use upon the area or populations was not undertaken. It also does not specifically study Afghanistan.

Thus, wider effects of drone use/strikes, beyond narrow measures of group violence levels, intensity, and/or group decline, remain at issue. Several studies stress this, whether emphasising targeted killing/decapitation, ${ }^{20}$ or particularly referencing drones. ${ }^{21}$ They also acknowledge the

\footnotetext{
${ }^{15}$ See, for example, Abrahms and Mierau, 'Leadership matters'; Johnston, 'Does decapitation work?; Price, 'Targeting top terrorists'.

${ }^{16}$ Studies finding them ineffective and/or counter-productive include: Aaron Mannes, 'Testing the snake head strategy'; Jordan, 'When heads roll'; Jordan, 'Attacking the leader missing the mark'.

${ }^{17}$ Abrahms and Siddique found little significant impact of these drone strikes on Taliban attacks in Afghanistan, but some significant reduction in Pakistan Taliban violence resulting from drone strikes in Pakistan. However, Abrahms and Mierau, found killing Taliban leadership in both Pakistan and Afghanistan had a 'modest' effect and 'promote[d] indiscriminate organizational violence'.

${ }^{18}$ Johnson and Sarbahi find drone strikes reduce violence in FATA, other parts of Pakistan and bordering areas of Afghanistan, and Mir and Moore find US drone use in Pakistan reduced violence in targeted areas. However, Rigterink found killing a terrorist leader by a drone increased violence levels significantly.

${ }^{19}$ Aqil Shah, 'Do U.S. drone strikes cause blowback? Evidence from Pakistan and beyond', International Security, 42:4 (2018), pp. 47-84, 55.

${ }^{20}$ Frankel, 'The ABCs of HVT', pp. 17-30, 26; Stephanie Carvin, 'The trouble with targeted killing', Security Studies, 21:3 (2012), pp. 529-55.

${ }^{21}$ Javier Jordán, 'The effectiveness of the drone campaign against Al Qaeda central: A case study', Journal of Strategic Studies, 37:1 (2014), pp. 4-29; Jacqueline L. Hazelton, 'Drone strikes and grand strategy: Toward a political understanding of the uses of unmanned aerial vehicle attacks in US security policy', Journal of Strategic Studies, 40:1-2 (2017), pp. 68-91, 86.
} 
need for wider assessment in context extends to policy goals beyond narrow, if statistically assessable, metrics of effectiveness in quantitative studies. Matt Frankel, Keith Patrick Dear, and Michael J. Boyle also raise important differences between counterinsurgency and counterterrorism, neglected in quantitative studies. ${ }^{22}$

Frankel emphasises the counterinsurgency/counterterrorism distinction noting the 'ability to predict second-order effects of the removal of key figures' is 'one of the most important, and overlooked drivers of success of an HVT [High Value Targeting] campaign', including 'understanding of the larger dynamics' that go beyond 'degradation of the group'. ${ }^{23}$ ' $[\mathrm{F}]$ inding the right balance between broader counterinsurgency efforts and HVT activities is vital.' And, '[t]his is where an overreliance on drone strikes can be problematic.' HVT, typifying counterterrorism operations, 'tend to be independent' of counterinsurgency efforts. ${ }^{24}$ Dear's study of targeted killing (including drone use), pays considerable attention to Afghanistan in finding 'targeted killing ... largely ineffective, and worse, is often actively counterproductive tactic in COIN [counterinsurgency]... [as] humans respond to fear by innovating, seeking revenge and uniting. ${ }^{25}$ Boyle distinctively highlights the importance of carefully considering the implications of concurrent counterinsurgency and counterterrorism efforts with specific reference to Afghanistan c. 2009-10.

Keith Dear and Christopher J. Fuller underscore the importance of context and both refer to factors pertinent to Afghanistan. Dear cites the significance of kinship ties and specifically Pasthun culture in parts of Afghanistan and Pakistan. ${ }^{26}$ Fuller observes 'the tribal regions which make up the FATA, the North-West Frontier Province (NWFP), and the border provinces of Afghanistan are all distinct regions, each with its own unique identity, tribes, culture, social groupings, and history. ${ }^{27}$ Shah's refutation of the 'blowback' hypothesis regarding drone strikes/targeted killing challenges some of the claims about tribal and cultural practices amongst Pashtun groups. In particular, his interview-based research suggests claims of drone strikes precipitating 'blood feuds' that see victims' relatives joining terrorist or insurgent groups reflect inaccurate colonial-era anthropological simplifications and misrepresentations. ${ }^{28}$ However, noncolonial era studies, such as by Akhbar S. Ahmed, support this. ${ }^{29}$ Also, Shah offers little by way of research-based correctives through contemporary anthropological and cultural insights into these varied groups.

\subsection{Counterinsurgency and counterterrorism}

Frankel points out profound differences between the end goals of counterinsurgency and counterterrorism: bringing 'the movement into the political process' and the 'elimination' of a terrorist organisation, respectively. ${ }^{30}$ US doctrine applicable during the fieldwork period confirms this. In counterinsurgency doctrine, 'the host nation must eventually provide a solution that is culturally acceptable to its society and meets US policy goals ${ }^{31}$... Ultimate success comes when a society maintains its own legitimate government and defeats its insurgency using its own resources, not

\footnotetext{
${ }^{22}$ Frankel, 'The ABCs of HVT'; Dear, 'Beheading the hydra?'; Boyle, 'Do counterterrorism and counterinsurgency go together?'.

${ }^{23}$ Frankel, 'The ABCs of HVT', p. 26.

${ }^{24}$ Ibid., p. 20.

${ }^{25}$ Dear, 'Beheading the hydra?', p. 325.

${ }^{26}$ Ibid., pp. 309-11.

${ }^{27}$ Christopher J. Fuller, See It/Shoot It: The Secret History of the CIA's Lethal Drone Program (New Haven, CT: Yale University Press, 2017), p. x.

${ }^{28}$ Shah, 'Do U.S. strikes cause blowback?', pp. 62-4.

${ }^{29}$ Akhbar S. Ahmed, Pakhtun Economy and Society: Traditional Structure and Economic Development in a Tribal Society (London, UK: Routledge, 1980).

${ }^{30}$ Frankel, 'The ABCs of HVT', p. 26.

${ }^{31}$ US Department of the Army, The U.S. Army/Marine Corps Counterinsurgency Field Manual (US Army Field Manual No. 3-24/Marine Corps Warfighting Publication No. 3-33.5) (Chicago, IL: University of Chicago Press, 2014) (hereafter FM3-24 2014), paras 1-6.
} 
through outside enablers. ${ }^{32}$ Therefore, it is unlikely to be as clear as in a conventional conflict. ${ }^{33}$ In counterterrorism doctrine, the expectation is 'there will never be a complete eradication of terrorism ... the ends of counterterrorism operations are the elimination of a terrorist's ability or willingness to conduct terrorist acts against the homeland/US facilities and interests abroad or facilitate other terrorist organisations to act against the United States. ${ }^{34}$ A paradox emerges: counterterrorism doctrine asserts the elimination of either the ability or willingness of terrorists to conduct attacks against the US and its interests (including abroad), although how much of an interest this is to Afghanistan (or others) is unaddressed. Furthermore, reconciling a 'solution that is culturally acceptable' to Afghanistan 'and its society' with one that 'meets US policy goals' that have been (re)prioritised to counterterrorism and the direct defence of America post- $c$. 2009-10 35 leaves limited common ground between the US and Afghanistan against terrorism and even less so against insurgency.

Boyle's analysis of conducting counterterrorism and counterinsurgency concurrently in Afghanistan up to c. 2010 questions their compatibility. ${ }^{36}$ '[T]he record of the war in Afghanistan suggests ... both models of warfare involve tradeoffs or costs that may offset the gains made by the other' and that they 'may operate at cross-purposes and make long-term strategic success more elusive. ${ }^{37}$ US doctrine provides additional support to his concerns as counterinsurgency and counterterrorism substantially differ in operational modalities. In counterterrorism the more 'kinetic' 'Defeat Mechanism' and the 'Find, Fix, Finish, Exploit, Analyze and Disseminate (F3EAD) process [is used] to plan for and execute all counterterrorism operations against terrorists and terrorist organizations and networks' in pursuit of cumulative effects. ${ }^{38}$ However, in counterinsurgency, effects occur in combination with reference to the 'Shape-Clear-Hold-Build-Transition Framework'. Counterterrorism effects are much more focused on the use of force in comparison to counterinsurgency. ${ }^{39}$ In counterinsurgency the population is the centre of gravity, rather than hostile forces, as in counterterrorism, which provides a key distinction. ${ }^{40}$ Moreover, although counterterrorism doctrine asserts effects are to be 'balanced' (including with counterinsurgency efforts), it is ambiguous as to what this, and what the two additional tenets of 'collaboration' and 'precision', mean. ${ }^{41}$ In 2014 and 2015, Afghan National Security and Defence Forces (ANDSF) continued to pursue counterinsurgency with support and guidance from the US and NATO-led troops, although the US focused mostly on counterterrorism. ${ }^{42}$ However, coordination was often difficult and lacking. ${ }^{43}$

Boyle similarly notes how counterinsurgency and counterterrorism involve different assumptions about the role of force, the importance of winning support among the local population, and

${ }^{32}$ Ibid., paras 7-39.

${ }^{33}$ Ibid., paras $1-25$.

${ }^{34}$ US Joint Chiefs of Staff, Counterterrorism (Joint Publication 3-26) (Washington, DC: 24 October 2014) (hereafter, JP3-26 2014), pp. I-5, V-1.

${ }^{35}$ Hew Strachan, The Direction of War (Cambridge, UK: Cambridge University Press, 2013), p. 259; Gareth Porter, 'How McChrystal and Petraeus built an indiscriminate "killing machine", Truthout (26 September 2011).

${ }^{36}$ Boyle, 'Do counterterrorism and counterinsurgency go together?', p. 336.

${ }^{37}$ Ibid.

${ }^{38} J P 3-26$ 2014, p. V-3.

${ }^{39}$ See, for example, JP3-26 2014, p. IV-11, compared with FM3-24 2014.

${ }^{40}$ David H. Ucko, 'Counterinsurgency after Afghanistan: A concept in crisis', PRISM, 3:1 (2013), p. 13. Usefully characterised as the interface of war's logic and grammar: Antulio J. Echevarria II, 'Reconsidering war's logic and grammar', Infinity Journal, 1:2 (2011), and a matter of judgement in the application of doctrine to specific situations as part of strategy. Thomas R. Mockaitis, The COIN Conundrum: The Future of Counterinsurgency and US Land Power (Carlisle, PA: US Army War College Press, 2016), pp. 6-7.

${ }^{41}$ JP3-26 2014, pp. II-1, II-2.

${ }^{42}$ See, for example, Azam Ahmed and Joseph Goldstein, 'Taliban gains pull U.S. units back into fight in Afghanistan', New York Times (29 April 2015); Special Inspector General for Afghanistan Reconstruction, 'Quarterly Report to the United States Congress' (30 July 2015), pp. 96, 105, 182.

${ }^{43}$ Discussions with Afghan government and military officers, diplomats, and international military officers. 
the necessity of building a strong and representative government. ${ }^{44}$ His elaboration through three main areas demonstrates how analysing and assessing drone use necessitates appropriate contextualisation including different policy goals, and the specific circumstances pertaining to Afghanistan.

Firstly regarding force, Boyle emphasises its discriminate and slow use in counterinsurgency because of the need to shape the preferences of the population. However, counterterrorism emphasises its swift use to eliminate terrorists. ${ }^{45}$ While counterinsurgency aims to draw the population towards the government using direct and indirect means to undercut support for the insurgency, counterterrorism does not. In pursuit of this aim counterinsurgency seeks to build the capacity of local government through the provision of security, governance, and development, but counterterrorism does not. ${ }^{46}$

Secondly, regarding winning the support of the local population, Boyle asserts counterinsurgency and counterterrorism involve different assumptions about the relationship between the local population and enemies. Boyle observes there is little evidence Al-Qaeda has wide support among the population in Afghanistan. Therefore, the use of force in counterinsurgency should weaken the insurgency without alienating the population or causing a significant backlash. Overall, Boyle cites the need for a political approach to address poor governance, poverty, and corruption, in addition to military challenges. ${ }^{47}$

Thirdly, regarding strong and representative government, a strict counterterrorism approach to military force does not involve a state-building component or an assumption of the need for 'territorial control'. Counterterrorism is premised on 'a lack of self-policing by the state', principally in areas of limited state capacity to maintain order such as 'ungoverned spaces'. Counterinsurgency, however, 'requires boosting the capacity of a government to exercise control over its own territory by countering the growth of the shadow government'. ${ }^{48}$ While this third point is broadly supported by applicable counterinsurgency and counterterrorism doctrine and US policy towards Afghanistan, it also reveals problematic assumptions and conceptualisations regarding context with important implications for assessing drone use (and other) effects. The influential conceptuality of 'failed states' and the interrelated conceptualities of [terrorist] 'safe havens' and 'ungoverned areas' exemplify analytical dangers of insufficiently contextualised assumptions.

Although no universal definition of 'failed or failing states' exists, ${ }^{49}$ US policy, and counterinsurgency and counterterrorism doctrine have explicitly employed these since 2002 to the fieldwork period. ${ }^{50}$ This is reflective of the problem [that counterterrorism] [had become] 'securitised', particularly by the US, and so was linked to economic backwardness, governmental weakness and religious fundamentalism'. ${ }^{51}$ As Robert D. Lamb has commented regarding 'ungoverned areas': 'few places in the world are truly "ungoverned"' 52 Nonetheless, the term

\footnotetext{
${ }^{44}$ Notably broadly aligning with: Ucko, 'Counterinsurgency after Afghanista', p. 13; David Kilcullen, 'Three Pillars of Counterinsurgency', remarks delivered at the US Government Counterinsurgency Conference, Washington, DC (28 September 2006).

${ }^{45}$ Confirmed by Michael V. Hayden, 'To keep America safe, embrace drone warfare', New York Times (19 February 2016).

${ }^{46}$ Boyle, 'Do counterterrorism and counterinsurgency go together?', p. 343.

${ }^{47}$ Ibid., p. 344.

${ }^{48}$ Ibid.

${ }^{49}$ Liana S. Wyler, 'Weak and Failing States: Evolving Security Threats and US Policy, Congressional Research Service Report for Congress, RL34253 (updated 28 August 2008), p. 4.

${ }^{50}$ Susan E. Rice, The New National Security Strategy: Focus on Failed States, report, Brookings (19 February 2003); The White House, 'The National Security Strategy of the United States of America' (May 2010), pp. 8, 11, 21; The White House, 'The National Security Strategy of the United States of America' (February 2015), pp. 4, 9; US Joint Chiefs of Staff, Counterterrorism (Joint Publication 3-26) (Washington, DC: 13 November 2009) (hereafter JP3-26 2009), pp. III-8; FM3-24 2014, pp. 2-7.

${ }^{51}$ Strachan, Direction of War, p. 268.

${ }^{52}$ Robert D. Lamb, 'Ungoverned Areas and Threats from Safe Havens', Washington, DC, Office of the Under Secretary of Defense for Policy (2008), pp. 4, 6.
} 
'ungoverned' had purchase, despite its elasticity. What constitutes 'effective governance' and 'good governance' in the context of Afghanistan is of far-reaching significance, as customary governance remains influential in political, security, and development efforts. Even though areas of Afghanistan, including those that border Pakistan (as do fieldwork areas) are 'one of the most unstable and strategically important places in the world ${ }^{53}$ a more complex reality frequently exists than these interlinked conceptualisations tend to admit. Such areas can be (as in the case of the fieldwork locations) largely self-governing and autonomous. They can also have historical loyalties to the Afghan state and central government, rather than be 'ungoverned' and '[terrorist] safe havens'. This adds to the need to carefully consider policy and interrelated counterterrorism and counterinsurgency efforts, including drone use, in context to more clearly understand their effects.

This section has summarised a twofold lack of contextualisation in analyses and assessments of drone use and its effects. Academic studies, particularly those employing statistical techniques, tend to limit context in pursuit of ostensibly objective statistically significant measures of the effectiveness (or otherwise) of targeted killing/decapitation, including drone strikes. This sees simplified, even incorrect, group designations, and definitions placed ahead of important contextual factors. Inconsistent geographical reference points neglect distinctions between conflict areas, and different data sources occlude key factors. Consequently, political, geographical, and cultural contexts are set aside or minimised resulting in problematic comparisons, or worse, and consequently limited conclusions. Secondly, in contexts where counterterrorism and counterinsurgency are both undertaken, such as Afghanistan, these efforts can be at odds with one another and involve different assumptions, emphases, techniques and policy goals, including under US doctrine. This is further guided and amplified by the problematic conceptualities of 'failed and failing states', 'ungoverned areas', and '[terrorist] safe-havens'. These misconstrue context and overlook the importance of local governance and related cultural institutions, social practices, and political dynamics, which historically enable populations to regulate their communities, and cooperatively oppose insurgents and terrorists. Thus, the need to appropriately contextualise drone use and its effects in order to understand and assess these becomes particularly apparent.

\section{Towards contextualisation}

\subsection{Fieldwork methods}

Fieldwork occurred between mid-September and late October 2015, involving thirty-seven in-depth, semi-structured interviews with Afghan men aged between (approximately) twenty and seventy-five. ${ }^{54}$ Random sampling was not possible under the circumstances. To reduce selection bias we indicated categories for respondents relevant to the localities to reflect a broad range of possible views among the local population. Twenty-two interviewees were subsistence farmers, eleven were Maliks (local tribally-related village/community chiefs), and four were from other groups. It was not viable to interview women given cultural and security sensitivities. Fieldwork was conducted by a leading Kabul-based research organisation with highly trained and experienced Afghan field researchers. It has carried out fieldwork for leading European and North American universities, NGOs, and foreign and development ministries. Interviews mainly occurred in two areas of eastern Nangarhar province: fifteen in the east of Lal Pur district and twenty-two in southern Nazian district. Fieldwork locations were selected based on publicly available drone use data including: The Bureau of Investigative Journalism (TBIJ) database; US military/NATO official statements; press releases from the Provincial Governor's office; and,

\footnotetext{
${ }^{53}$ Gilles Dorronsorro, 'The transformation of the Afghanistan-Pakistan border', in Shahzad Bashir and Robert D. Crews (eds), Under The Drones Modern Lives in the Afghanistan-Pakistan Borderlands (Cambridge, MA: Harvard University Press, 2012), p. 30.

${ }^{54}$ Two aged 18-25; four aged 26-35; ten aged 36-45; twelve aged 46-55; five aged 55-65; three aged 65 and over; one unknown.
} 
contemporary press reports. These locations experienced intensive drone use in the period preceding the fieldwork and occupy strategic border locations often referred to as 'safe haven' areas. Continuing review established drone use intensity persisted or subsequently increased.

Interviews were informed by three pre-existing assertions regarding drone use in general and relevant to the context of Afghanistan: (1) done properly, targeted killings can strengthen support for the host government, which is key to defeating an insurgency; ${ }^{55}$ (2) drones may reduce tensions between peacebuilding activities and waging war; ${ }^{56}$ and, (3) drone strikes (and use) do more good than harm. ${ }^{57}$ Posing these claims directly could be leading and delimiting in the context of Afghanistan. Therefore, research questions, developed in consultation with experienced Afghan researchers, aimed to enable indirect assessment of these assertions and generate in-depth insight. Consequently, testable hypotheses were not an explicit element of our data gathering strategy.

Interviewees were asked about: (1) personal experience(s) of drone use, and views about drone use in Afghanistan and Pakistan; (2) understanding of the relationship between drones and the US and NATO; and (3) views of the effects of drone use. More detailed subquestions were agreed to ensure comparability while recognising respondents' experiences and willingness to discuss topics could vary. Consequently, sequencing of questions was at fieldworkers' discretion. No direct questions about counterinsurgency or counterterrorism were asked, as it was considered these concepts might not be sufficiently clearly understood by interviewees. Full details of the questions are in the online supplementary material.

Fieldwork researchers proceeded to the fieldwork locations after indepth briefings including the director, senior members of the research organisation, and at least one co-author. These addressed the importance of unbiased selection, research aims, ethics, and consultation and clarification of the questions (including translation). Review and research ethics approvals took place within Durham University's procedures. Fieldworkers had substantial prior knowledge of the fieldwork locations.

Respondents were interviewed separately in private for precision and safety. Occasionally, respondents were interviewed outside the fieldwork area by mutual agreement. Typically, each interview lasted 30-45 minutes, with more than one interview as appropriate. Aiming to move beyond conditioned and group expectation induced responses, ${ }^{58}$ an interviewing style built on rapport and empathetic understanding' was employed. ${ }^{59}$ This methodologically reflexive attitude is well suited to the sensitive nature of such discussions. ${ }^{60}$

An 'ethnographic' methodological approach was employed to understand individuals' perspectives and thoughts, responses, and actions via their own experiences, ${ }^{61}$ and from within their culture as they attempted to interpret situations in order to act. ${ }^{62}$ Factors were considered in context, utilising 'a combination of empirical investigation and subsequent subjective understanding of human phenomena' ${ }^{63}$

\footnotetext{
${ }^{55}$ Frankel, 'The ABCs of HVT', p. 18.

${ }^{56}$ Astri Suhrke, 'Waging war and building peace in Afghanistan', International Peacekeeping, 19:4 (2012), p. 489.

${ }^{57}$ Avery Plaw, 'Drones save lives, American and other', New York Times (14 November 2012).

${ }^{58}$ Paul Highgate and Ailsa Cameron, 'Reflexivity in researching the military', Armed Forces and Society, 32:2 (2006), pp. 219-33.

${ }^{59}$ Elaine Campbell, 'Interviewing men in uniform: A feminist approach?', International Journal of Social Research Methodology, 6:4 (2003), pp. 285-304, 289.

${ }^{60}$ Jonathan Goodhand, 'Research in conflict zones: Ethics and accountability', Forced Migration Review, 8 (2000), pp. $12-15$.

${ }^{61}$ Fredrik Barth (ed.), Ethnic Groups and Boundaries: The Social Organization of Cultural Difference (Bergen, Norway: Universitetsforlaget, 1969); Clifford Geertz, The Interpretation of Cultures (New York, NY: Basic Books, 1973), pp. 33-54.

${ }^{62}$ Geertz, The Interpretation of Cultures, pp. 345-59; Alan Tongs, 'The philosophical basis of Geertz's social anthropology', Eastern Anthropologist, 46:1 (1993), pp. 1-17.

${ }^{63}$ Mark R. Woodward, 'Hermeneutics', in David Levinson and Melvin Ember (eds), Encyclopaedia of Cultural Anthropology (New York, NY: Henry Holt, 1996), pp. 555-8 (p. 555).
} 
Complementing this, Grounded Theory methodology was employed to enable exploration of integral social relationships and the behaviour of groups, including where there has been little exploration of the contextual factors affecting individual's lives. ${ }^{64}$ This also enabled exploration of further approaches, for example, ethnography, cultural and political anthropology, and potentially social network analysis, as identified by Kathy Charmaz. ${ }^{65}$

Throughout preparations, the fieldwork, and during follow up, personal and research biases are unavoidable. Therefore, there has been consistent and extensive reflection and discussion with members of the research team, self-reflexive analysis, and comparison with the widest array of human and documentary sources possible. Discussions with a range of long-established independent contacts knowledgeable about and in direct contact with the fieldwork areas has confidentially crosschecked details and results. ${ }^{66}$

Interviews were transcribed in Pashtu and translated by the research organisation into English. We hand-coded results against question areas for consistent comparative analysis. In presenting results, we have randomly assigned numbers between 1 and 100 and minimised possible identifying characteristics to ensure interviewees' anonymity. Each transcript is limited to no more than three citations; ensuring identification is not possible through crosschecking. Where interviews are quoted, we report the fieldwork organisation's translations, correcting only clear spelling or punctuation errors, or standardising spelling. Where we believe there is clear reason to adjust transcripts, this is indicated by square parentheses.

\subsection{The fieldwork locations in eastern Nangarhar}

Understanding context of the interview sites involves multiple dimensions, including the inhabitants, their customs, practices, culture, organisation, and historical experiences. This enables interview results to reveal appropriate drone effects, and analysis and assessment of their significance. Despite their relative geographical proximity, the two fieldwork locations significantly differ in context, indicating commonalities in drone effects are likely more generalisable.

Inhabitants interviewed in Lal Pur were from either the Murad khel subtribe of the Mohmand (eleven) or the Miyagan (four), which is spiritually related to the Mohmand. All Nazian interviewees were from the Sangu Khel subtribe of the Shinwari. Interviewees strongly self-identified with their respective tribes and subtribes, and customary behaviours. ${ }^{67}$ This is unsurprising as the Mohmand and Shinwari tribes are amongst the most united in Afghanistan. ${ }^{68}$

Both tribes have, at different junctures, supported the central government politically, providing renowned soldiers and leaders to attack an external enemy, or protect it against internal

\footnotetext{
${ }^{64}$ Dauna L. Crooks, 'The importance of symbolic interaction in Grounded Theory research on women's health', Health Care for Women International, 22:1-2 (2001), pp. 11-27.

${ }^{65}$ Kathy Charmaz, 'Grounded Theory', in J. Smith et al. (eds), Rethinking Methods in Psychology (London, UK: Sage, 1995), pp. 27-49; Kathy Charmaz, 'Grounded Theory analysis', in J. F. Gubirum and J. A. Holstein (eds), Handbook of Interview Research (Thousand Oaks, CA: Sage, 2002), pp. 675-94.

${ }^{66}$ Validity procedures were carried out following Table 1 in John W. Cresswell and Dana L. Miller, 'Determining validity in qualitative inquiry', Theory Into Practice, 39:2 (2000), pp. 124-30, 126.

${ }^{67}$ Barth's insights were applied in assessing the diacritical features and basic value orientations of the cultural contents of ethnic dichotomies; see Barth (ed.), Ethnic Groups and Boundaries, pp. 13-14. Consideration of the Mohmand tribe (also present over the border in Pakistan) employed Ahmed, Pukhtun Economy and Society. See also Shahmahmood Miakhel, 'The importance of tribal structures and Pakhtunwali in Afghanistan: Their role in security and governance', in Arpita Basu Roy (ed.), Challenges and Dilemmas of State-Building in Afghanistan: Report of a Study Trip to Kabul (Delhi, India: Shipra Publications, 2008); Bernt Glatzer, 'Is Afghanistan on the brink of ethnic and tribal disintegration?', in William Maley (ed.), Fundamentalism Reborn? Afghanistan and the Taliban (London, UK: Hurst, 1998), pp. 167-81.

${ }^{68}$ David Mansfield, 'All Bets Are Off? Prospects for (B)reaching Agreements and Drug Control in Helmand and Nangarhar in the Run Up to Transition', The Afghanistan Research and Evaluation Unit (AREU) (January 2013), pp. 5-45, 28-31; Antonio Giustozzi, Koran, Kalashnikov and Laptop: The neo-Taleban Insurgency in Afghanistan (London, UK: Hurst, 2007), p. 62. Also, enquires with field researchers, inhabitants of the eastern region, academics (including Afghan), and Afghan and international civilian and military government officials.
} 
uprising. ${ }^{69}$ They have also both rebelled against the central government with serious results, ${ }^{70}$ and adopted a neutral position in the face of others' rebellions. ${ }^{71}$ Mohmand and Shinwari men have served in the central government due to their estrangement from fundamentalists, ${ }^{72}$ and other engagements reflect political hedging strategies. ${ }^{73}$

The Mohmand tribe, and its 'distinct hereditary leaders', has historically had 'intimate relations with the Kabul government', ${ }^{74}$ reflecting its geo-strategic location. Central government granted the tribe special concessions, for example exemption from conscription in the 1980s, reflecting their status and culture. The current leader of the Mohmand tribe has worked with numerous Kabul governments, including the (Communist) People's Democratic Party of Afghanistan (PDPA), and has had generally good relations with the post-2001 Afghan government including at the most senior levels. ${ }^{75}$ An 'enduring and almost symbiotic relationship between the Afghan state and the Mohmandi tribal elite' exists. ${ }^{76}$

The Mohmand and Shinwari tribe have historically been fierce rivals, partly as a result of their geographical and other proximities, and significant differences between the two tribes (and their subtribes) exist. Yet, as will be seen, fieldwork results show very little variation despite this.

In Nangarhar, parts of adjacent provinces, and Pakistan the Shinwari have a long and proud history of resisting 'interference' in their independence from central and other authorities. According to Ahmed's typology, they are Nang (honour) Pashtuns: tribes with an egalitarian society possessing three critical features: a low material standard of living, an absence of political authority, and a rigid adherence to customary laws. Contrastingly, Qalang (taxed) Pashtuns are settled, pay taxes (qalang), and represent a hierarchal society having centralised political authority, a complex and prosperous economic life, and an impersonal legal system. ${ }^{77}$ Although Ahmed finds that the Mohmand are Nang Pashtuns, ${ }^{78}$ the Mohmand in the fieldwork location do not precisely fit either Nang or Qalang typologies, having features of each. For example, the Mohmand in the fieldwork location are ostensibly untaxed, although exhibit a more centralised authority alongside customary laws.

Comparatively, the Shinwari, and in particular the Sangu Khel in the Nazian fieldwork location, closely match the Nang typology. While the Shinwari are organised on a segmentary basis with allegiance according to multiple and dynamic relationships, and leadership manifesting as elders (Khans) whom are primus inter pares, a permanent tribal elite has emerged in the Mohmand. ${ }^{79}$ Both tribes have largely hereditary Maliks, whom are influential at the village/community (a group of villages) level. ${ }^{80}$ Non-hereditary Malik incidence and influence has gradually increased in recent years, owing largely to distortions created by international aid/development projects, and pressure from insurgents. ${ }^{81}$

\footnotetext{
${ }^{69}$ Peter Thomsen, The Wars of Afghanistan: Messianic Terrorism, Tribal Conflicts and the Failures of Great Powers (New York, NY: Public Affairs, 2011), pp. 70-3.

${ }^{70}$ Leon B. Poullada, Reform and Rebellion in Afghanistan, 1919-1929 (Ithaca, NY: Cornell University Press, 1973).

${ }^{71}$ William R. H. Merk, The Mohmands (Lahore, Pakistan: Vanguard Books, 1984).

${ }^{72}$ Antonio Giustozzi, War, Politics and Society in Afghanistan, 1978-1992 (London, UK: Hurst and Georgetown University Press, 2000), p. 132.

${ }^{73}$ Regarding contemporary political dynamics in Nangarhar province involving Shinwari and Mohmands, with implications for Afghanistan's national politics, see David Mansfield, 'The Devil is in the Details: Nangarhar's Continued Decline into Insurgency, Violence and Widespread Drug Production', AREU (February 2016).

${ }^{74}$ Merck, The Mohmands, p. 17, quoted in ibid., p. 21.

${ }^{75}$ According to field research and interlocutors.

${ }^{76}$ Mansfield, 'All Bets Are Off!', p. 22.

${ }^{77}$ For discussion of the Nang v. Qalang concept, see Ahmed, Pakhtun Economy and Society.

${ }^{78}$ Ibid., Kindle loc. 1231 of 8150.

${ }^{79}$ Akbar S. Ahmed, Social and Economic Change in the Tribal Areas (Karachi, Pakistan: Oxford University Press, 1977), p. 14; Benjamin D. Hopkins and Magnus Marsden, Fragments of the Afghan Frontier (London, UK: Hurst, 2012).

${ }^{80}$ Thomas H. Johnson and Chris M. Mason, 'No sign until the burst of fire: Understanding the Pakistan-Afghanistan frontier', International Security, 32:4 (2008), pp. 41-77, 61.

${ }^{81}$ Multiple sources: fieldworkers, tribes via interlocutors, local academics, and officials.
} 
James Scott describes groups such as these as inhabiting 'non-state space' and as 'selfgoverning peoples', ${ }^{82}$ conflicting with conceptualities of 'failed and failing' states, 'ungoverned' and 'safe havens' so influential in US policy and doctrine. The Afghan state has limited, but is not devoid of, influence over individual and group behaviour in these areas. ${ }^{83}$ Jirgas remain central cultural institutions in maintaining and regulating identity and behaviour at the village level, at a (larger) 'meso level' (accessed depending on the issue), and at the 'macro level' (the main tribal jirga). Each of these jirgas is relevant to the fieldwork locations. ${ }^{84}$ Our research findings concur with that complex interplay of governance institutions and processes at multiple levels in Nangarhar province. As David Mansfield states, 'the interests of local elites and rural populations ... tie .... outlying districts of rural Afghanistan to elite groups in both Jalalabad and Kabul' and a 'complex web of interrelationships and bargaining processes between provincial and local elites and the rural population is highly contextualised, a function of the history, political economy and specific space and territory. ${ }^{, 85}$ Also, as Thomas Ruttig states, it is not too late to strengthen the internal cohesion of certain tribes and their particular institutions by supporting their ability to re-establish functioning, legitimate decision-making bodies (jirgas, shuras) that can allow other political forces than the Taliban to play a stronger role again. ${ }^{86}$ Extant drone analysis pays little, or, more frequently, no attention to these governance institutions and processes in context. Our results suggest that, in eastern Nangarhar at least, those effects are crucial to fully and accurately analysing and assessing drone effects.

\subsection{Analysing fieldwork results}

We employ a modified version of Boyle's four 'off-setting effects' to analyse interview results, informed by the importance of local context and cognisant of problematic assumptions about 'failed states', 'ungoverned' areas and 'safe havens'. The first 'offsetting effect' is 'popular backlash': 'the application of sudden, lethal force' in counterterrorism can 'inflame local opinion against the local government' making gaining its support more difficult, undermining counterinsurgency. This includes transgression of Afghan cultural norms about the sanctity of the home and insensitivity and disrespect to local traditions, as well as civilian casualties. Such backlash risks serious political fallout. ${ }^{87}$

The second is 'countermobilisation of enemy networks'. Public outrage from Special Forces raids and drone strikes is an important issue. Although there is limited evidence of recruitment into militant networks in reaction to such raids and strikes, ${ }^{88}$ other potential effects include the accelerated radicalisation of existing political groups, and encouraging them to make common cause with jihadi groups. Indirect costs include the loss of intelligence from dead operatives and losing the moral high ground from civilian casualties. ${ }^{89}$

The third is 'legitimacy gap'. Boyle states 'both counterinsurgency and counterterrorism ... depend on political capital', however, the former should 'build the political capital of the local government' while the latter 'requires the government to use its political capital in authorizing costly or unpopular missions'. Therefore, if this produces a government with a legitimacy gap, it 'will have diminished political capital and face higher costs for complying with

\footnotetext{
${ }^{82}$ James Scott, The Art of Not Being Governed: An Anarchist History of Upland Southeast Asia (New Haven, CT: Yale University Press, 2009).

${ }^{83}$ Hopkins and Marsden, Fragments of the Afghan Frontier, p. 216.

${ }^{84}$ According to a dedicated social study, and focused investigations including researchers, academics and local, national and international officials.

${ }^{85}$ Mansfield, 'All Bets Are Off!', pp. 20-1.

${ }^{86}$ Thomas Ruttig, 'How tribal are the Taliban', in Bashir and Crews (eds), Under the Drones, pp. 102-35, 134.

${ }^{87}$ Boyle, 'Do counterterrorism and counterinsurgency go together?', pp. 344-6.

${ }^{88}$ See, for example, Shah, 'Do U.S. strikes cause blowback?'.

${ }^{89}$ Boyle, 'Do counterterrorism and counterinsurgency go together?', pp. 346-50.
} 
counterterrorism demands'. ${ }^{90}$ Boyle claims the Karzai government had a legitimacy gap, particularly after the problematic 2009 presidential elections and through allegations of 'mismanagement, incompetence and corruption'. In 2014-15, the Ghani government and National Unity Government arguably had a weaker electoral mandate. However, although Karzai was rather uncooperative with the US from c. 2008, President Ghani has been cooperative on counterterrorism, lending credence to Taliban and Al-Qaeda narratives it is illegitimate and a puppet regime, as Boyle warns. ${ }^{91}$

The fourth is 'leverage', pertaining to that a 'foreign backer has over its partner government'. ${ }^{92}$ Counterterrorism cooperation depends on leverage for partner governments to authorise costly counterterrorism operations. In the case of Afghanistan in the fieldwork period this is less of a concern as the Afghan-US Bilateral Security Agreement provides considerable latitude for the US to mount unilateral operations. ${ }^{93}$ However, the 'exploitation' of US (and NATO) commitment to Afghanistan, Boyle notes, remains an issue, ${ }^{94}$ and the US still requires Afghan cooperation for intelligence and support for effective counterterrorism and counterinsurgency.

\section{Fieldwork analysis}

Turning to our specific fieldwork findings, the depth of insights into 'offsetting effects' through contextualisation becomes apparent. Understanding the situation in locations in eastern Nangarhar more fully enables far greater appreciation of the effects of drone use.

\subsection{Witnessing drone strikes}

All thirty-seven respondents had seen drones, and eighteen reported daily drone presence in the recent past. Ten reports noted multiple simultaneous drone presence, consistent with USAF, JSOC, and CIA practices, especially in the period immediately prior to strikes when multiple drones are often used for intelligence gathering. Many respondents were aware that some drones, including those involved in strikes, fly too high to be seen or heard, adding to their fear of sudden strikes. Twenty-five interviewees reported directly witnessing strikes (one reported surviving a strike) or attending strike sites within approximately one hour. Interviewees described directly experienced drone strikes and reports from relatives or social contacts, which were distinguished. Both types of experience stretched back to early 2014, totalling sixty-eight strike descriptions. These were crosschecked against TBIJ's database to help identify multiple reports of the same strike, and, potentially to fix strike dates and locations as closely as possible. Given very low literacy levels in these locations, respondents were rarely clear about dates, although they frequently identified the part of the day when attacks occurred, reflecting the importance of daily rhythm to pastoral and agricultural activities integral to life in eastern Nangarhar. Resultantly, one strike description could be confidently identified, with nine more significantly correlating with TBIJ-listed strikes. Some reports were clearly of the same strike, but descriptions are insufficiently specific to definitively establish the scale of overlap. Therefore, it is reasonable to suggest interviewees described approximately sixty separate strikes.

Respondents offered detailed descriptions of the aftermath of attacks, particularly against vehicles, which accounted for forty-one strike descriptions. Fourteen interviewees (seven Lal Pur, seven Nazian) described burnt corpses, and the challenge of identifying, collecting, and sorting body parts into piles or bags. The effect of munitions centred on the burning of bodies with

\footnotetext{
${ }^{90}$ Ibid., p. 350.

${ }^{91}$ Ibid., p. 351.

${ }^{92} \mathrm{Ibid}$.

${ }^{93}$ Kate Clark and Thomas Ruttig, 'Three Birds with One Stone: Signing the BSA and NATO SOFA to Project Reliability', Afghan Analysts Network (6 October 2014).

${ }^{94}$ Boyle, 'Do counterterrorism and counterinsurgency go together?', p. 352.
} 
associated emphasis upon the 'flaming' quality of drone-launched missiles. In Islam, burning bodies is considered haram (forbidden/proscribed), ${ }^{95}$ reinforcing respondents' negative assessments of the US role in Afghanistan as an occupier manipulating a weak government as part of a wider anti-Muslim agenda. Drone strikes amplified accusations and narratives of US reluctance to face/communicate with locals, juxtaposed by a willingness to kill at a distance and desecrate bodies.

Among many descriptions, the following are illustrative. Interviewee 44 described one strike in May 2015:

I saw a drone attacking a Toyota car ... I heard a blast ... when I looked up ... there was dust all over the place and ... I noticed smoke rising from the attacked car ... the car was burning .... We have a rule among us that we don't get near the accident right after it happened because we are scared of being attacked by drone. After ... a while people started walking towards the accident point. I also got there and I saw ... its passengers were ... thrown far away from the car and ... turned black ... their faces were not recognisable. There was ... fear in people's eyes and everyone was looking [in] the air ... afraid of drone's comeback and ... bombarding. It was such a scary sight that I have never seen before in my life. I almost [vomited] and was stunned watching people burning in fire. ... I had a headache for three days.

Interviewee 62 described strike effects similarly: 'It was 2 o'clock in the afternoon .... After one hour people came out of their houses .... Horror seemed in everyone's face. When I saw the dead bodies [of those] were killed cruelly I [was] fed up with life. ... They had been burnt so badly their faces couldn't be recognised. Everyone hates drones.'

Interviewee 96 observed:

It was around 9pm and ... we heard a sudden sound of a blast, its sound shook whole village. We said 'Allah who has been attacked now?' [T] here was complete silence in the village, nobody was talking. ... An hour passed ... dust and malodour [dissipated]. ... We heard someone say, 'Hey! Village people I am injured come and help me.' Nobody dared go near the injured person ... if we went then [a] drone [might] attack us as well. ... He shouted 'til the morning but no one went to help him. People went [closer] in the morning and saw a person half burned [and] dead [who] was the person who shouted for help. It seemed like there were a few more [in the car] but they were chopped in pieces .... [It] was burned and people were also [blackened] like ashes.

These testimonies indicate instances of 'popular backlash' via drone strikes' culturally and religiously condemned effects, even in circumstances where respondents supported strikes against the 'right' people.

\subsection{Living with drones, insurgents, and terrorists}

Alongside specific strike details, transcripts reveal populations experiencing immense stresses, reflecting fear of strikes, and disruption to already marginal subsistence livelihoods based on agriculture and limited trade. Significantly, no respondents expressed support for insurgent groups' political projects; most rejected them, and all reported experiencing disruption caused by insurgent and terrorist presence and drone operations. 'Popular backlash' was evident in twenty-three interviewees (twelve Lal Pur, eleven Nazian), identifying the Afghan government as powerless or

\footnotetext{
${ }^{95}$ For indication of the sensitivity, see Jessica Donati, 'Last Western prisoner leaves Afghanistan after pardon', Wall Street Journal (8 August 2016).
} 
bypassed in drone strike decision-making, consequently alienating interviewees. Contra Shah's narrow use of 'backlash' as only relating to joining militant organisations, ${ }^{96}$ Boyle's framing supports richer analysis through contextualising different forms of popular response to drone use and strikes. Interviews also reveal weakened customary governance institutions and dislocation of people underscoring alienation and resentment. Two interviewees in Lal Pur are typical. Interviewee 14 explained:

The biggest influence it had on our people is they [inhabitants] started leaving the village and now we don't have even fifty homes nearby in the village. Another ... effect ... is they cannot do their work in the field because Taliban walk around the village and fields ... and no one can tell Taliban to leave this place because we are afraid ... and [there is] fear that a plane [or drone] will attack any time so they are very frightened .... Before, people were busy in the mountains collecting wood, transferring it in the market through animals and they would sell it .... But now Taliban from one side and non-Muslims from the other side have forced people to sit at home even if they are dying of hunger.

Interviewee 6 reinforces the account of displacement: 'Most of the people in (region within Lal Pur) left their homes and went to other areas since their lives and personal assets were in danger. Most of them shifted to [redacted] and [redacted] districts where they are facing a lot of problems ... because they have their animals with them, but they don't have their own fields in those places to feed their animals'.

Interviewee 96, from Nazian, described similar outcomes there: 'We have many problem[s] with drone[s], we have agricultural lands and ... animals .... [I]n [the] past we had worked in our land and take animals to mountain but when these drones start ... bombing in our village ... we can't go to our lands, we can't take our animals to mountain so no one go outside of village and home because everyone scare that the drone will shoot .... Most of our youths going to foreign countries.' Three interviewees discussed the customary practice of carrying a firearm, and emphasised how fear of being misidentified as Taliban and targeted by drones had stopped economic activity such as herding animals in mountains occupied by predators, or tending particularly remote fields.

Respondents were fully aware of the presence of, and distinctions between, (Afghan) Taliban and other groups, such as Tehrek-i-Taliban Pakistan, Lashkar-I-Islam, foreign fighters, and (particularly among respondents interviewed later in the research period), ISIL-K. Interviewees routinely encountered members of these groups as they moved through the locale, with some respondents noting the intermingling of local populations and insurgent membership, or in one case describing personal friendships with the Taliban. Illustrative accounts indicate local people's awareness of different groups' presence, and how counterterrorism and counterinsurgency activities, including drones, affected those groups and their relationships to locals. Interviewee 26 in Lal Pur stated:

Taliban ... are scared of drones and are afraid of being shot by them.... The other effect ... the drones have had on Taliban is that they never let the people from other groups ... enter the areas that are under their control because whenever the number of Taliban increases in an area, ... [it] gets targeted by drones. Our area ... is under the occupation of Tehrek-i Taliban. Some time ago, there was a conflict among them and Islamic Emirate [Afghan Taliban], because the ... Tehrek-i Taliban asked them [Afghan Taliban] to [go to] the other area because we want to attack Pakistan from here and your existence in this area makes it difficult for us to live here since [drones would attack us].

${ }^{96}$ Shah, 'Do US strikes cause blowback?'. 
In Nazian, where descriptions of ISIL-K presence concentrated, Interviewee 9 highlighted ISIL-K extremism, and also the fear inspired by drones: 'Daesh [ISIL-K] have created such atrocities that we should thank drones. Drones are there to prevent them and Daesh are [only] afraid of them. Because those wild and ruthless people are not even afraid of God.'

Thirteen interviewees (five Lal Pur, eight Nazian) noted drones' effectiveness at disrupting Taliban and other groups' operations by inducing fear. However, this reinforced pressures from insurgent/terrorist groups on local families. Locals in both fieldwork locations were strongly expected to provide hospitality, including tea, food, and accommodation (such as in the male guest house or hufra), according with deeply held principles of melmastia (hospitality) in Paktunwali. ${ }^{97}$ Interviewee 96 summarises several respondents' views: 'There are lots of Taliban here who pass our house or sometimes ... rest in front of our house or ask us to bring tea or food. At these moments our family members ... fear ... if drone see them and bombard them then we will die as well.'

Detailed incidences of strong pressure or coercion from the 'visitors' were provided. For example, families with a member working for the Afghan government or military were warned not to welcome them home, or have any contact with them. ${ }^{98}$ Interviewee 40 , a Malik, commented: 'There is ... worry in our area, if people join army then ... when they come to village ... they have even faced danger of being killed by Taliban.' Three interviewees (two Lal Pur, one Nazian) described local religious leaders refusing to offer funeral prayers for ANDSF personnel from their area, fearing insurgents' retribution or because of their co-option by insurgents. Duress included threats of accusations of spying for the US or collaborating with the Afghan government, typically punishable by death, if shelter and hospitality were not provided. Another Malik, Interviewee 70, explained: 'The Taliban are coming ... to our homes, we are not inviting them ..., they are coming by ... force ..., and the people have to provide them some food and other things and also sit with them and behave properly, and whenever you sit with them inside your home, you are always afraid that we might come under the target of the drones, and if we don't sit with the Taliban ... they would ... most probably say that you are American's spy or agent and that is why we would not let you live.'

Interviewee 26 described a similar experience: 'Whenever someone from Taliban is being shot by ... drones ... they ask us to take their partners to hospitals, or, if they are dead ... to ... bring their ... bodies to them and if we don't then they ... blame us of being spies for ... foreigners.'

Ten interviews (four Lal Pur, six Nazian) describe eroding community relations and trust because of concern at accusations of spying or informing related to drone use. Customary sources of Pashtun honour (nang) ${ }^{99}$ - and the honour of the respective hosts, communities and (sub) tribes - were resultantly heavily impacted by insurgents' and terrorists' behaviours following drone strikes (and the lack of protection from the Afghan government or US/NATO-led forces). Specific examples include demanding melmastia in a threatening manner; allegations against hosts; and, invading sensitive areas of the home, such as the hufra, without invitation; and, the threat of entering areas where women were present. In turn this impacted the maintenance of relations and ethnic boundaries, with ramifications for authority and order in the area, the group, and its governance. ${ }^{100}$

\footnotetext{
${ }^{97} \mathrm{Hufra}$ relates to one of main prestige conferring symbols of tribal society (the others being the jirga (council) and the topak (gun)). Ahmed, Pukhtun Economy and Society, Kindle locs 297, 5986.

${ }^{98}$ Mohmand and Shinwari are 'border tribes'. Both Afghan authorities and foreign supporters have found it hard to recruit them. Antonio Giustozzi, The Army of Afghanistan: A Political History of a Fragile Institution (London, UK: Hurst, 2015), pp. 54, 57. In these areas, nationalist feelings run high because of suffering perceived to originate from Pakistan. A high degree of cohesion, ability to self-rule and self-govern exists. Giustozzi, Koran, Kalashnikov and Laptop, pp. 62-3.

${ }^{99}$ Barth (ed.), Ethnic Groups and Boundaries, p. 120. Barth refers to izzat (honour), congruent with nang (honour). See also Ahmed, Pukhtun Economy and Society, Kindle loc. 3536.

${ }^{100}$ Barth (ed.), Ethnic Groups and Boundaries, pp. 119-23.
} 
Following drone strikes, insurgents and terrorists interrogate locals, frequently involving allegations of enabling drone strikes by providing information or physically marking people, vehicles, or structures. Interviewee 74 explained: 'Before, it was ... said ... drones hit their targets according to ... SIM cards and they cannot hit any target without those .... People were saying that the spies put some sorts of chips in the pockets of Taliban and then they are ... targeted by drones. Therefore, Taliban killed several people whom they thought were doing this.'

Interviewee 9 was blunt: '(I)f suddenly a blast happen[s], Taliban and Daesh will behead us in accusation of reporting and spying on them.'

\subsection{Weakened governance}

These incidences and dynamics directly impact locals' ability to 'do Pashtu'101 such as: honouring invitations from other communities; providing hospitality to one another and other communities; offering and attending marriages, funerals, and celebrations; engaging in farming and fishing practices when drones are very active; meeting to organise and discuss these matters with other locals; and, calling, attending, and participating in jirgas. ${ }^{102}$ A number of (sub)tribal Khans (elders/chiefs) from both tribes and subtribes had moved out of the area, several of which need to be met with in order to maintain relations, cultural boundaries, and behaviours, and engage in ongoing customary regulation and governance of the community via jirgas. Maliks from both subtribes also reported being prevented from convening or taking part in jirgas as a result of drone activities.

Every interviewee described disruptions from drones damaging customary governance, consequently weakening customary relations, cultural boundaries, behaviour, community cohesion, and security. ${ }^{103}$ This caused further stresses on daily existence. Particularly impacted were honour (nang) with regard to protecting women and children, including their psychological wellbeing; ${ }^{104}$ the ability for elders to obtain, deliver, and distribute moral and material goods; and, to fulfil, maintain and regulate customary roles, influence, and governance.

Important social occasions for 'doing Pashtu', for example, weddings and funerals, were smaller than hitherto due to drones. Attendees reportedly arrived as late as possible within the bounds of social acceptability, and left early, especially before nightfall. They feared large gatherings might be mistaken for insurgent/terrorist group gatherings and attacked by drones. The size of gatherings was also affected by expressed distrust of those outside the area or unknown to locals who might be members of groups likely to attract drone strikes.

Interviewee 36 highlighted damage to the social fabric of communities, reflecting many comments across the sample: '[B] efore we used to gather a lot but now we try to avoid gatherings. We try to avoid going to each other's homes .... More importantly, we try to avoid making relations with newcomers or strangers, because it's hard to trust everyone. We cannot recognise the person whether he is a terrorist or a good person or if he is a target of drones or not.'

Nineteen interviewees (eleven Lal Pur, eight Nazian), described Maliks' marginalisation regarding drones. Elders were described as: refusing to discuss the issue of drones; co-opted or coerced by the Taliban; unable or disinclined to take up the issue with provincial or national officials, or through customary means; and, less able to resolve matters because of decisions made by foreigners. A Malik, Interviewee 70, noted in frustration the impact on usually influential customary governance figures and institutions: '[T]he political elders do have some kind of symbolic role, they do not have any power [in the circumstances now], I do not think that our views ... matter [to those] who take decision[s].'

\footnotetext{
${ }^{101}$ Ibid., p. 119.

${ }^{102}$ Based on Ahmed, Pukhtun Economy and Society, and fieldwork findings.

${ }^{103}$ Barth (ed.), Ethnic Groups and Boundaries, pp. 117-34.

${ }^{104}$ Ahmed, Pukhtun Economy and Society; Miakhel, 'The importance of tribal structures and Pakhtunwali in Afghanistan'. Psychological harm is similar to findings regarding drones in FATA; see Cavallaro et al., 'Living under drones'.
} 
This marginalisation matters because Maliks' standing among the population depends heavily on their ability to influence other authorities and to secure funding, projects and support for their community. Although Maliks can have vested interests in being seen to support practices considered de facto permitted/endorsed by national and provincial governmental authorities, including security institutions, pressure also exists in both fieldwork areas for Maliks to be appointed who are pliant to particular interests and overlapping constituencies, ${ }^{105}$ exacerbating their vulnerability resulting from marginalisation.

Of fourteen (six Lal Pur, eight Nazian) accounts of discussions of drone strikes with religious leaders, a substantial majority report Mullahs condemning drones and the US. Reasons include indiscriminate attacks, the non-Muslim faith of the US, and the necessity for Muslim solidarity against foreign intervention in Afghanistan. Indeed, fifteen (eight Lal Pur, seven Nazian) respondents asserted narratives of a continuing war against Muslims via drones. Resultantly, Khans' and Maliks' ability to refute religious figures calling for jihad and extreme actions in response to drones has been seriously undermined. This is consistent with Ahmed's observation regarding (Mohmand) Maliks: 'the weight of their word depend[s] to a great extent on their personal influence'. Maliks' lack of a relationship with drones and those using them is not lost on the local populace. Consequently, Maliks' influence in moderating behaviours and balancing religious figures in the area has been impacted, ${ }^{106}$ weakening customary governance. While Boyle's 'legitimacy gap' emphasises the national level, interviews reveal a comparable problem in the fieldwork locations resulting from drone use. Customary governance practices in Nazian and Lal Pur militate against radical and extremist jihadist political groups, but are being seriously weakened including by drones. This works against both the US's overarching policy goal regarding 'failed or failing states' and related conceptualities, its counterinsurgency goal, and causes undesirable effects in relation to its counterterrorism goal in strategically crucial locations.

\subsection{Further alienation from government and international actors}

Twenty-three interviewees (twelve Lal Pur, eleven Nazian) identified the Afghan government as powerless or bypassed in drone strike decision-making, speaking to Boyle's 'popular backlash', 'legitimacy gap' (such as vulnerability to narratives of illegitimate government and governance), and 'leverage' (for example, potential cooperation for costly operations/strikes including intelligence).

Research beyond the fieldwork locations revealed further alienation and problems indicative of these 'offsetting effects' and of 'counter-mobilisation', too. A wide range of interlocutors describe multiple discussions of drone activities at Nangarhar Provincial Council (PC), including proximate to the fieldwork period. In 2014, it closed its doors to the central government protesting at inaction about drone use in the province. PC members include influential tribal figures, such as a close relative of the head of the Mohmand tribe in Afghanistan, and others with interests in the fieldwork locations. The Provincial Governor has raised effects and implications of drone activity multiple times with Afghan and international military officials at local and national level since 2014. MPs for parts of the province (including those tribally linked), and the tribal leadership of the Mohmand and Shinwari, have raised concerns in Parliament. Indeed, detailed conversations about drone activity occurred with civilian and military officials in Kabul at the very highest levels. Similarly, jirgas at the meso and macro levels have discussed drone use; the extent and gravity of concerns mean issues have been considered at the main tribal jirgas. The perceived (and actual) inability of the main tribal jirgas to obtain much information about

\footnotetext{
${ }^{105}$ Per discussions with interlocutors familiar with fieldwork locations. This is largely consistent with Antonio Giustozzi, 'If only there were leaders: The problem of "fixing" the Pashtun tribes', in Magnus Marsden and Benjamin D. Hopkins (eds), Rethinking the Swat Pathan (London, UK: Hurst, 2012), pp. 239-47.

${ }^{106}$ Ahmed, Pakhtun Economy and Society, Kindle loc. 1411, also confirmed by interlocutors.
} 
drone activities has created great frustration. The lack of perceived results on the issue of drones, and most pressingly drone strikes, has significantly impacted perceptions of the nang of figures, about which particular concern was expressed among interviewees and other interlocutors. This further indicates a 'legitimacy gap', and ramifications for 'leverage', particularly intelligence and wider cooperation.

Widely held and intensifying resentment of the Afghan government, and especially the US, results from the perception the US was 'the cause' of impacts from drones. Interviewee 33, from Lal Pur, asserted:

Drone attacks are for the benefit of NATO, ISAF and American forces .... I do think the Americans and NATO couldn't face Taliban face-to-face in the war and the Taliban defeated them, and now to have some kind of result ..., they are carrying out those attacks ... a good and clear path for them, because their soldiers are not getting killed by these attacks .... [T] heir target is to hit five or ten insurgents but they are putting millions of people under deep stress .... The benefit goes to the government, but it is a big loss for us, the drone attacks can have temporary effects but the Taliban are not less, their manpower is not less, so these attacks are putting negative effects on the people.

Illustratively, fifteen interviewees (eight Lal Pur, seven Nazian) highlighted the non-Muslim faith of the US and/or NATO states as a reason for their lack of care for Afghans, and contributing to interviewees' antipathy. Others stressed civilian casualties from drone strikes, an important element of 'popular backlash'. Resulting alienation and resentment clearly impacted trust in the government and US/NATO-led forces, undermining current and prospective support essential for counterinsurgency, and impacting cooperation and intelligence provision for counterterrorism, and thus 'leverage'.

Fieldwork researcher debriefings revealed younger respondents (aged thirty and under) demonstrated especial angst about drones. Several expressed the desire to travel to Jalalabad, Nangahar's capital, where they believed the drones were operating from the US base, 'to try to put a stop to them'. Numerous elders and parents stated since drone strikes had begun youth were more open to radical and extreme views. They noted community means of managing these views had been circumscribed by drone activity restricting gatherings. While it is unclear if drone use is accelerating extremism among existing insurgent/terrorist groups, indications exist; for example, pressure placed on local populations around spying or informing on insurgents. Regarding 'counter-mobilisation', the aforementioned incidents involving youths, interviewees' expressions of religious solidarity through concern about non-Muslims killing Muslims, anger at civilian casualties, and weakening informal governance constraints on behaviour are cause for serious concern.

US drone use in these remote regions has clearly alienated populations with historical loyalties to Kabul. Prospects for fulfilling policy goals are challenged by counter-productive and 'offsetting' effects resulting from drone use. Goals of shaping the environment, supporting development of 'legitimate government', and both actions and cooperation against insurgents and terrorist groups are seriously impacted by drone use, with longer-term implications. These outweigh short-term benefits drone use and strikes bring. Provincial government influence, even in the capital Jalalabad, and its extension into remote regions is important yet delicate, ${ }^{107}$ which drone use in the fieldwork locations and elsewhere has impacted. The Mohmand and Shinwari tribes and their subtribes in the fieldwork locations are important examples of actors, institutions, and related processes profoundly misunderstood by conceptualities of 'failed states', 'ungoverned' areas, and '[terrorist] safe-havens' directly informing US policy, counterterrorism and counterinsurgency doctrine, and efforts.

${ }^{107}$ Mansfield, 'The Devil is in the Details'. 
We identified three broad claims supportive of drone strikes to be indirectly tested through fieldwork: (1) done properly, targeted killings can strengthen support for the host government, which is key to defeating an insurgency; (2) drones may reduce tensions between peacebuilding activities and waging war; and, (3) drone strikes (and use) do more good than harm. In fieldwork locations in eastern Nangarhar none of these is borne out. Any support gained by killing the 'right' people via drones, such as insurgents/terrorists, is undermined through fear, serious social and economic disruption, and deleterious effects on local communities and governance institutions with short and longer-term ramifications for counterterrorism, counterinsurgency, and peacebuilding. In addition to drones, national and international efforts/support against insurgents and terrorists is highly limited providing a useful 'test' of drone use. On this evidence, and considered in appropriate context, drone use and strikes have been doing more harm than good.

\section{Conclusion}

We set out to demonstrate how drone analysis suffers through a lack of appropriate contextualisation, why it needs to change, and what can be achieved through appropriately contextualised analysis.

Section 1 showed a twofold lack of contextualisation with leading, mostly statistical, academic studies of drone effectiveness overlooking crucial context including employing different definitions, data, and highly questionable composite designations regarding groups and areas. Their lack of differentiation between insurgencies and terrorism exacerbated the lack of context. Qualitative studies, while more attuned to context, seldom consider its wider and deeper importance to analysing and assessing targeted killing/decapitation/drone effectiveness or its relationship with policy goals and doctrine. However, they have raised important concerns about context and the pursuit of counterterrorism and counterinsurgency in the same area. Secondly, we showed how US policy and doctrine also display deep-seated difficulties with problematic conceptualisations of 'failed and failing states', 'ungoverned areas', and '[terrorist] safe havens' that are not context-appropriate. This reinforces Boyle's arguments that pursuit of counterterrorism and counterinsurgency together can be at cross-purposes, and also by locating divergent doctrinal policy goals. Precluding appropriate appreciation of customary governance via erroneous policy and consequent doctrinal assumptions is particularly damaging.

Sections 2 and 3 established why a more contextualised research design offers valuable insights into drone effects, and what those are in fieldwork locations in eastern Nangarhar. Enquiring into the conditions in locations where drone use occurs, rather than deriving hypotheses from abstract behavioural models, produces a responsive research design that learns from and adjusts to the context it is applied to. Detailing the distinctive context of the two study areas reveals how customary governance rooted in historically evolved practices is dynamically inter-woven with Afghanistan's central government institutions and practices. This both undermines the claims/ assumptions of a 'failed state', 'ungoverned' and '[terrorist] safe-haven', and reveals how drone use/strikes in these areas are especially damaging to these governance institutions. Boyle's offsetting effects proved a useful heuristic for enquiring into effects with appropriate adjustments, for example, 'legitimacy gap' is applicable to local and not only central/national governmental institutions. Similarly, 'popular backlash' encompasses wider concerns with governance institutions and 'leverage' can see acute focus on the need for host government support, local intelligence, and cooperation despite US unilateral strike capability.

Without appropriate context, these insights are unavailable to analysis and assessment of drone use or for improving drone use. Boyle's argument about the challenges of simultaneously pursuing counterterrorism and counterinsurgency is borne out, but with new insights helping identify specific consequences in the fieldwork areas and elsewhere in Afghanistan. Measuring intervention effectiveness by, for example, 'disrupted' or 'degraded' terrorist organisations, 
while overlooking implications for local and national security, governance, capacity building and statebuilding, badly skews measures of success or effectiveness, rendering them not only highly questionable but also counterproductive.

Acknowledgements. We gratefully acknowledge the advice and guidance of four anonymous referees for EJIS, and from Professor Roger Mac Ginty, who read a complete draft of the paper. Initial fieldwork analysis benefited greatly from feedback received following a workshop held at St Aidan's College, Durham University (with thanks to the Principal Professor Susan Frenk) and presentations at the Universities of St Andrews and Glasgow. The late Dr Iain Edgar also encouraged us, provided invaluable insights and made numerous suggestions as we developed this project, as did Colonel Iain Smailes (British Army (Rtd) and a former UK Defence Attaché to Afghanistan), as well as several Afghans who remain anonymous given security conditions in Afghanistan. Shortcomings, errors, and omissions are, of course, our responsibility.

Supplementary material. To view supplementary material for this article, please visit: https://doi.org/10.1017/eis.2021.19

James Michael Page is an Honorary Fellow in the School of Government and International Affairs, Durham University. Before going up to Durham as a Senior Research Fellow he served as a Political Affairs Officer with the United Nations Assistance Mission Afghanistan between 2009 and 2015 as Special Assistant to the Director, Political, and the lead (Political) for Security Sector Reform, Transition, and Transformation. He is also a Visiting Scholar at the Afghan Research and Evaluation Unit. His writings on Afghanistan have been published by the Royal United Services Institute, and on the Gulf by the Durham University Institute for Middle Eastern and Islamic Studies. Author's email: james.page@ durham.ac.uk

John Williams is Professor of International Relations in the School of Government and International Affairs, Durham University. His research focuses on the ethical and security implications of developing military technologies, including drones and autonomous systems. His work on these topics has appeared in Ethics \& International Affairs; Global Policy; and the Journal of Global Security Studies. Author's email: j.c.williams@durham.ac.uk

Cite this article: Page, J. M., Williams, J. 2022. Drones, Afghanistan, and beyond: Towards analysis and assessment in context. European Journal of International Security 7, 283-303. https://doi.org/10.1017/eis.2021.19 